\title{
The Temptations of Lying
}

\author{
Wolfgang Heuer \\ Privatdozent, Otto Suhr Institute for Political Science, Free University Berlin \\ Managing Editor of HannahArendt.net \\ Address: Ihnestraße, 21, Berlin, Germany 14195 \\ E-mail: wolfgang.heuer@gmx.de
}

\begin{abstract}
The lie accompanies us, it is parasitic on the truth and indispensable in our everyday life. But how can we limit it and prevent it from destroying the truth? This question is particularly topical given the so-called "post-truth" phenomenon of fake news, conspiracy theories and populist propaganda. Arendt's analyses of the relationship between truth and lies in politics are helpful. To defend facticity, truth is indispensable, but factual truth resists limitless freedom of speech and action, or, in Arendt's words, our enlarged mentality. Imagination is the common ground for creativity, the design of another world, but also for lies. Therefore, politics and lies are structurally very close, though of course not the same. Contemporary populist movements use lies in order to undermine the credibility of other politicians and mass media. The boundaries between truth, lies, the denial of reality, invented truths as well as, for example, anti-Semitism and racism are dissolving. Conspiracy theories are the pinnacle of the loss of reality. In contrast to lies, they offer a closed parallel world in which nothing happens by accident and nothing is what it seems. Zygmunt Bauman's term retrotopia indicates that globalization and technological change are leading to growing uncertainty and a discrediting of policies, which meet with populist aims. Arendt's republicanism offers an alternative to both, populism and consumer liberalism: the defense of facts, enlightened criticism and a concept of a qualitative plurality of engaged citizens.
\end{abstract}

Keywords: truth, post-truth, lying, enlarged mentality, plurality

Lying is practiced in both the private and the public realm, including politics. Psychological research has shown that we lie as many as 200 times a day. Austrian scientist Peter Stiegnitz introduced the scientific study of lies, or mentiology, which distinguishes five forms of lying: the self-deceptive lie to suppress uncomfortable truths; the white lie to keep friendship unharmed; the prestige lie to impress people; the anxiety lie to avoid the disagreeable consequences of one's own actions, and the unscrupulous lie to deceive, disadvantage, misinform or mislead others for self-benefit (Stangl). One could add the obsessive, pathological lie or pseudologia fantastica, as in the case of a man in Switzerland who dressed as an orthodox Jew in the 1980s and 199os, inventing and living out his life story as a child survivor of the Holocaust in Auschwitz (Wilkomirski, 2002).

A lie cannot exist without the truth. It is a "parasite of the truth" (Dietz, 2003: 43-44; Bettetini, 2003), its opposite, and frequently its partner. In ancient times, Plato approved of lying for the benefit of the common weal (Politeia, Book III). During the Renaissance, Castiglione's The Book of the Courtier declared dissimulation to be the duty of courtly

(c) Wolfgang Heuer, 2018

DOI: $10.17323 / 1728-192 X-2018-4-25-36$

(c) Centre for Fundamental Sociology, 2018 
conduct, while Machiavelli saw lies and violence as a legitimate means of domination in defense of the republic and Torquato Accetto, whose work On Honest Dissimulation was published in 1641, recommended placing a "veil of honest darkness" over life's sad truths. In modern times, Leo Strauss distinguished between the philosopher's truth, reserved for the ruler, and pious myths and illusions, i.e., religion and morals, alleged to be good for the masses (Strauss, 1959). ${ }^{1}$

Philosophy was more puristic: St. Augustine refused to accept lies or any excuse for lying, while Kant, with reference to metaphysics and politics, strongly declared that a lie always harms someone else, "if not some other particular man, still it harms mankind generally, since it vitiates the source of justice" (Kant, 1889: 363). With this argument he rejected Benjamin Constant's reasoning that lying was legitimate if a murderer, for example, were to enquire about the location of a potential victim.

Nietzsche, on the other hand, adopted a radically different perspective. Rebelling against conventional morals and their corresponding practices, he considered lies to be business as usual and truth a construct of illusions. "This art of dissimulation reaches its peak in man. Deception, flattering, lying, deluding, talking behind the back, putting up a false front, living in borrowed splendor, wearing a mask, hiding behind convention, playing a role for others and for oneself-in short, continuous fluttering around the solitary flame of vanity" According to Nietzsche, men "are deeply immersed in illusions and in dream images; their eyes merely glide over the surface of things and see 'forms'... Their senses nowhere lead to truth; on the contrary, they are content to receive stimuli and, as it were, to engage on the back of things." Truth, Nietzsche says, is "a movable host of metaphors, metonymies, and; anthropomorphisms ... illusions which we have forgotten are illusions - they are metaphors that have become worn out and have been drained of sensuous force." He concludes that we are dealing with a "great columbarium of concepts, the graveyard of perceptions" (Nietzsche, 2006: 117). It is not Nietzsche's intention here to nihilistically question all access to truth, but rather to suggest the stoic man of reason lay aside "his masterpiece of deception" and "with dignified, symmetrical features" even "when a real storm cloud thunders above him," walk "with slow steps . . from beneath it." In other words, not to be a slave to concepts and the game of creating them, but to acquire instead the independence of the non-conformist in both thought and action.

This is the path Arendt chooses. Unlike Kant's formal analysis and Nietzsche's perspective of cultural and epistemological criticism, Arendt concentrates on the lie as a political phenomenon, simultaneously discussing the existential-philosophical dimensions of lies and the truth. This was against the backdrop of the heated debate on her report of the Eichmann trial in Jerusalem, an experience that confronted her with the significance of factual truth and truth-telling, and the exposure of the truth about the Vietnam War waged by the United States in the 1960 s and 1970s, which led her to question the temptation to lie in politics. We cannot ignore the fact that "post-truth" lies have currently taken

1. See Robert Pippin: "Strauss believed that good statesmen have powers of judgment and must rely on an inner circle. The person who whispers in the ear of the King is more important than the King. If you have that talent, what you do or say in public cannot be held accountable in the same way" (Hersh, 2003). 
on a new form. Can Arendt's analysis help us to deal with the lies that are prevalent in contemporary politics and society?

In answering this question, I will discuss the following aspects:

- Arendt's position on truth and lies in politics and human existence;

- the new "post-truth" phenomenon of fake news, conspiracy theories and populist propaganda;

- the underlying conditions of this post-truth and where they differ to those of the political lies Arendt faced in her time;

- Arendt's concept of qualitative pluralism as an effective antidote to the "post-truth" phenomenon.

\section{Arendt's Position on Truth and Lies}

The publication dates of the essays on this topic are several years apart. "Truth and Politics" was published in 1964, shortly after her report on the Eichmann trial appeared, while "Lying in Politics" came out in 1971 following the publication of the Pentagon Papers by The New York Times. Each essay was Arendt's response to a current debate. She constantly responded to the challenges of the day and saw it as her civic responsibility, one that forced her to think, to judge and, at least as an observer and author, to act. In the course of a discussion with friends she declared: "What is the subject of our thought? Experience! Nothing else! And if we lose the ground of experience then we get into all kind of theories" (Arendt, 1979: 308). All her writings were motivated by current events.

The two essays are closely linked. Given Arendt's pathos about a new beginning and political action, anyone who hopes to find a definition of politics that is bound to truth and effectively excludes lying will be sorely disappointed. Her two basic insights on truth and lies are: the truth is apolitical, whether it appears in the form of historical facts, i.e., as factual truth that is immovable and cannot be destroyed by any attempt to conceal it, or in the form of a conviction, as a truth of reason, which, declared as the only valid truth, becomes tyrannical and is directed against human plurality. Error, illusion or opinion are the opposites of the truth of reason; the opposite of a factual truth is a lie.

In comparison to truth, lies are structurally closer to action. "The deliberate denial of factual truth - the ability to lie - and the capacity to change facts - the ability to act are interconnected; they owe their existence to the same source: imagination" (Arendt, 1972: 5). Action and lying come from the same mental source, a place in the mind where we distance ourselves from reality and truth. When Arendt defined enlarged mentality in her posthumous writings on the capacity to judge as the capacity to imagine an abundance of plural opinions through which common sense is set in motion and universally valid judgments are made, she knew it also had the potential to serve the development of non-plural thinking, disparate judgments, dissimulation and concealment from the public eye. Hence her statement on thinking as dangerous, but not thinking as far more dangerous, clearly evidenced in the case of conformists or careerist bureaucrats such as Eichmann. 
The truth can be uncomfortable and is not always convenient. In everyday life, a small lie tends to be the lubricant that prevents processes from stagnation. Not always telling the truth, not saying everything that could be said is the basis of our daily dealings and political diplomacy. It allows for smoother cooperation. However, there are factual truths that dare not become the victim of diplomacy: historical truths such as the genocide of the Armenians by the Ottoman authorities (today's Turkey) and the mass murder of Jews under the German Nazi government. In Arendt's view, denying these facts means watering them down into opinions so as to strip the truth of its mandatory nature. There is a strong link between the conscious negation of facts and action, which is generally guilty of negating facts in the interests of unfettered behavior. Here, the liar has the advantage of knowing what people do not want to hear, that is, uncomfortable facts (Ibid: 6). The ardent nationalist cannot accept the fact that the Armenians were slaughtered as a security measure by the Ottoman state and its people. The fact that the Vatican pursued a pro-fascist policy during World War II was highly unpleasant for many Catholics after the war, while the French were reassured by the declaration that despite its defeat by Hitler, France belonged to the victors. Since historical facts - bare facts - always require interpretation and meaning, they are vulnerable. Arendt's portrayal of Eichmann and of the Jewish councils caused an outcry among the survivors: her report on his trial in Jerusalem described Eichmann not as a monster, but as someone whose inability to question or think for himself manifested itself in the unspeakable language he used, which was riddled with clichés; Arendt described the cooperation of the Jewish councils installed by the Nazis in the occupied countries as a very dark moment in Jewish history. Facing up to these uncomfortable truths caused her tremendous pain. The portrayal of Eichmann as a monster and of the victims as completely innocent would have been much more conciliatory. In a letter to Arendt, her friend, publisher Helen Wolff, quoted from the speech delivered by Socrates in his own defense: "Don't be angry with me when I speak the truth" (Arendt, 2017: 593) - but they were angry. Since time immemorial, the messenger has always been punished. Those who succumb to this threat, however, are entering dangerous territory: "What is at stake here is this common and factual reality itself, and this is indeed a political problem of the first order" (Arendt, 2006: 232).

In summary, according to Arendt this means that "our ability to lie - but not necessarily our ability to tell the truth - belongs among the few obvious, demonstrable data that confirm human freedom... It is this freedom that is abused and perverted through mendacity" (Ibid.: 246).

A striking example of this is the lie about the Vietnam War, according to which North Vietnam attacked an American battleship, forcing the United States to launch a war of self-defense. In addition, the unleashing of war by the US without the vote of Congress was a violation of the constitution. According to Arendt, dispensing with the idea that reality had to be concealed by a lie was new in the Vietnam era. Instead, facts and opinions were manipulated to such an extent that the difference between truth and lies was no longer visible. It was all about the image of the invincible US. Warfare had detached itself completely from reality and depended on "problem solvers," cyberneticists and futurolo- 
gists. Unlike the lie as a parasite of the truth with expert knowledge of it, the Vietnam War and its transformation of the truth bore witness to the loss of the reality of the war and the conditions in Indochina at the time. Deceiving the opposition and the voters led to selfdeception, the most dangerous form of lie (Ibid.: 249). The US president, surrounded by advisors and problem solvers, seemed to be the very person who was most manipulated and most isolated in his own country.

In Arendt's analysis, three protagonists are responsible for the derealization and fiasco of the Vietnam War: the intellectuals who were keen to act politically as problem solvers, the isolated and unsuspecting president, and the lack of monitoring activities by the senate, all of which made it impossible for the separation of powers to effectively enable criticism, defend the truth and put a stop to derealization.

Already, the fundamental difference between these circumstances and the current "post-truth" phenomenon is apparent. I will address this in the next section.

\section{The New So-Called "Post-Truth" Phenomenon: Fake News, Conspiracy Theories and Populist Propaganda}

The Vietnam War lie was a lie organized by the ruling circles and their intellectuals in the sense of Leo Strauss, and we encounter it again in the amateur lie about the alleged weapons of mass destruction in Iraq, which the US proclaimed in the UN security council in 2002 to justify their planned invasion.

Current lies are quite a different matter. No longer presented by the government for the alleged good of the nation, lies are now a double act: practiced by politicians and certain sections of the population. Their common aim is to change the balance of power, not by using the enlightened nature of truth-telling to defend reality, but on the contrary, by derealizing reality with the help of lies. Communication developments on the internet, especially using social media, allow for information exchange and the creation of pressure groups to a hitherto unimagined extent and with breath-taking speed. The Australian political scientist John Keane invented the term "post-truth" to describe the obvious transgression of the standard of truthfulness valid up to now. A "post-truth" differs from a lie in this case, whereby a lie is merely one of several means of confronting the truth with other truths or with "alternative facts," as US President Trump's advisor Kellyanne Conway called them. Factual truths are dissolved into opinions and vice versa, opinions become facts - alternative facts. During his first presidential year, Trump made 2,00o false statements, that is, between five and six each day. According to Keane, "post-truth" consists of lies, bullshit, buffoonery, gaslighting and endless exaggeration (Keane, 2018). This characterization applies notably to the US government, which has abandoned the traditional relationship between truth and lies.

Israeli sociologist Eva Illouz claimed that Trump mocks "any principle and any axiom of communicative action and rationality in the public space: He lies constantly and disregards the principle of at least giving the impression of speaking the truth. He challenges the validity of science and consequently the existence of objective criteria by which com- 
peting claims can be evaluated. He vigorously challenges the notion of a common world for all men and women. For him, there is only one world, comprised of people who support him and his interests - his denial of global warming is but one example of this. His communication with other nations shows that he is not even interested in pretending to work towards a common understanding" (Illouz, 2017). Whether Mexico, the EU, NATO, North Korea or China - Trump's statements change constantly for no plausible reason. He never tires of emphasizing that regardless of the challenge, he is the greatest, the most knowledgeable and the best. "He gives his own personal feelings free rein, be they feelings of hurt or the desire for revenge, making him a private person in charge of the country" (Ibid). In a similar manner, populist parties and politicians in Europe seek to destroy truth with propaganda: Marine Le Pen's fake news videos to discredit state media during the electoral campaign; at a time when thousands of Syrian refugees were arriving in Germany, the newspaper report falsely claiming that the young daughter of Russian immigrants had been kidnapped and raped by men who looked Arab, which led the Russian community in Berlin to call for a mass demonstration; the designation of the media as "the lying press" and the denial of global warming; the claim by a growing number of people, 15,00o to date, that the German Empire had never been dissolved and that therefore no one in Germany today was obliged to follow the rules of the authorities; many in this group are armed; one police officer has been killed.

The boundaries between truth, lies, the denial of reality, invented facts, and anti-Semitism and racism are blurred. It is only a short step from the xenophobic assertion that Germany has become the target of Islamization to the racist claim that refugees are causing a population exchange that will culminate in the genocide of the "white race." Conspiracy theories thrive in such a climate and are highly effective when it comes to undermining truth and reality: from the Protocols of the Elders of Zion to the alleged truth about 9/11 and the condensation trails left by planes, which are in reality "chemtrails" laced with chemical additives to reduce the size of the population. Contrary to lies, conspiracy theories offer a closed parallel world, in which nothing happens by chance, nothing is what it seems and everything is connected. The conspirators are the elites, ranging from the Queen, the Rothschilds, and the German chancellor to the Illuminati or freemasons, or all of them combined. Those who enter these parallel worlds are largely immune to criticism, which is claimed to be part of the conspiracy, thus ultimately confirming its existence in the first place (Feuerbach, 2017; Butter, 2018).

\section{The Conditions that Led to "Post-Truth" in Contrast to the Political Lies Arendt Faced in Her Time}

I have already discussed, the fundamental distinction between a state lie and the enlightening nature of truth-telling in defense of reality, on the one hand, and populist lies, on the other hand, that show politicians and certain sections of the population working together in an attempt to destroy reality. Why is this strategy so successful within large parts of the population? Eva Illouz interprets Trump's election not so much a "result of 
ideological convictions (apart from a minority), but rather of an immense rage that has accumulated in American society without an addressee" (Illouz, 2017). Unlike in Arendt's time, criticism here does not serve constructively for the future. On the contrary, it serves to reject change, not in the sense of utopia or heterotopia, but retrotopia, to borrow Zygmunt Bauman's term. In his view, the current historical phase is marked by "back-to tendencies . . . notably the rehabilitation of tribal models of community, the resort to the image of an original/unspoiled 'national identity', whose destiny is predetermined by non-cultural factors and those that are immune to culture." This tendency is enhanced by the prevailing belief in the social sciences and among popular opinion that "there are essential, non-negotiable sine qua non preconditions for a 'civilizing order"' (Bauman, 2017: 17-18). This popular but illusionary notion of a cast-iron cultural identity has now reached racist circles, with the "Identitarian Movement" in Austria, Germany and France demanding that all peoples should stay in their own nation.

The Edelman Trust Barometer survey carried out in twenty countries in 2017 found a high degree of insecurity among the population, and a lack of trust in the media and information. $63 \%$ said they were unable to distinguish between quality journalism and fake news; $80 \%$ feared that fake news would influence elections and 50\% followed the news less than once a week (Edelman Trust Barometer).

According to Bauman, retrotopia is the result of a general uncertainty caused by the delimitation of job markets, wars and migration, political and social insecurities, the end of an optimistic future, or indeed of a safe future, and the death of the great narratives such as liberalism or socialism. Furthermore, familiar values and roles are undergoing a shift. In Eastern Germany, for example, a fundamental insecurity of middle-aged and older men with regard to their roles following the reunification of Germany has been observed. They, in particular, are the men who support right-wing parties and movements (Machowecz, 2017). Their retrotopia emerges where former male values such as physical strength, leadership and binary problem-solving form of the either-or alternative predominated. Eva Illouz's description in her Adorno lectures in Frankfort in 2004 of "feelings in capitalist times" (Illouz, 2007) disconcerts these men: the therapeutic society and its narrative of personal responsibility and self-realization, the vast attention given to the role of a victim, the emotionalization of the product world and the de-emotionalization of privacy, as well as the "transformation of the public arena into a showcase for privacy, emotion and intimacy" (Ibid.: 160).

This general sense of discomfort leads to a longing not for plurality, interdependencies and relations, but rather for unambiguousness, an either-or truth, the $I$ among the We against Them, the others. It is the search for a truth that is found in unambiguousness and interprets reality from this perspective and sensitivity.

In the quest for unambiguousness, there is a rejection and an active fight against all things insecure: experts, the media, refugees, the European Union, the Euro and referendums for greater economic cooperation, for example with Ukraine. It is easy to find like-minded people on the internet and create a comfort zone, an echo chamber, a hall of mirrors. "Free from the unsettling and discouraging cacophony of reality, the comfort 
zone is a place where nothing else is heard but the noise produced by oneself, nothing is seen but the reflections of what is similar to oneself" (Bauman, 2017: 184). Here, the feeling of sovereignty and control returns; likewise the sense of no longer being a helpless victim, but one with the right to defense by any means. The emotion that sustains this self-isolation is rage for its own sake; when it turns to violence, then for the sake of violence. Ordinary citizens are capable of attacking their fellow citizens with hate and lies in a manner hitherto unknown ${ }^{2}$. This is the climate of self-righteousness and mob justice.

On the political level, this orientation leads to a revoking of plurality and the splitting of society. Populist movements declare themselves to be the genuine representatives of the "people," at the same time excluding all others as non-people and as enemies of the people. Since a society's democratic-republican constitution rests on and institutionalizes the plurality of both opinion and action, revoking it inevitably weakens its institutions. This is clearly visible in the current efforts of populist governments in Poland and Hungary to undermine the separation of powers to the advantage of the executive. Arendt's statement that freedom is the meaning of politics implies that without the practice of plural, diverse thought and action, freedom will wither away.

Liberalism, at least in its characterization by Rawls, fails to provide a viable alternative (Kreide, 2016). Up until now, we have for the most part seen the deficits of democratic institutions in terms of legitimacy and agility, including Post-democracy by Collin Crouch and Democracy without Demos by Catherine Colliot-Thélène. Thoughts on greater participation have been suggested by Claus Leggewie, for example, and a reform of the electoral system in favor of the lottery procedure has been proposed by, among others, David Van Reybrouck (Crouch, 2004; Colliot-Thélène, 2017; Nanz, Leggewie, 2016; Reybrouck, 2016). There is, however, an absence of ideas that see this era of change as the interrelationship between globalization, retrotopia and a shift in economic and political power at international level.

Since retrotopia is directed against the globalization that affects us all, it is a global occurrence rather than a phenomenon exclusive to some individual states. It merges with traditional autocratic methods of organization and forms sustainable governments. As John Keane points out, the focus of international trade and the global economy is gradually shifting eastwards, to a region extending from Turkey and Saudi Arabia to India, Southeast Asia and China, whose economic growth rates have the potential to give legitimacy and stability to "despotisms," as Keane calls them. This process is enhanced by the fact that Europe's strength and importance for the global economy and world politics is diminishing by a similar proportion. The same holds true for the United States in the wake of the Obama administration. This vast region in the East is clearly not pursuing the long tradition of European Enlightenment or an enlightened understanding of politics, so that neither Tocqueville nor Montesquieu can offer assistance in absorbing the situa-

2. See the report of a constantly persecuted German journalist who reported on the terrorist attack in Nizza as an eye witness and a short time later on the attack in Munich. At the same time he rejected theories claiming these terrorist attacks were the work of an international conspiracy to conquer the world (Gutjahr, 2018: 6). 
tion (Keane, 2015). Keane observed that "these despotisms ... have their own 'reality' we resemble the blind, each examining different part of an elephant's body in the dark and on the basis of traditional knowledge attempting to grasp what kind of creature it is. Undoubtedly, we need to rethink the old concept of despotism. We erroneously tend to perceive despotism as a political system in which violence vents its fury unrestrained. . . New despotisms are different, more subtle, much more efficiently organized and focused on stability" (Ibid.: 29f.). Are we dealing with a new form of despotism? Are we in the same situation as Tocqueville, who at the intersection of aristocracy and democracy was forced to admit that "Our heritage was left to us without a testament"?

\section{Arendt's Concept of Qualitative Pluralism}

This concept is beyond neo-liberalism and authoritarianism, that is, beyond a quantitative pluralism that interprets pluralism merely as a multitude of different people and opinions, on the one hand, and the resultant desire for simplification and unambiguousness, on the other. The seemingly extreme juxtaposition of an unlimited mass and a restriction on diversity through leadership leaves room for the collective and the individual, but not for distinctiveness and personality. In her book The Human Condition, Arendt defined the "fact of human plurality" as "the basic condition of both action and speech" and characterized this plurality as "the twofold character of equality and distinction. If men were not equal, they could neither understand each other and those who came before them nor plan for the future and foresee the needs of those who will come after them. If men were not distinct, each human being distinguished from any other who is, was, or will ever be, they would need neither speech nor action to make themselves understood" (Arendt, 1958: 156). This existential duality is the basis of civilized society. Its institutions, the separation of powers, the public realm and any form of opinion-making must guarantee room for its development. As a matter of interest, the concept of plurality also contradicts that of the sovereign nation state in favor of the federation as a further pivotal form of vesting the powers of government in separate bodies (see Heuer, 2016). Arendt is certain that the stubbornness of facts is superior to all power constellations. Even totalitarian ideology, with its large-scale attempt to substitute reality entirely with its compelling logic, failed.

This, however, calls for protagonists to defend truth and reality. The proximity of the necessary interpretation of factual truths, to grasp their meaning and the falsification of facts, and to avoid unpleasant consequences clearly testifies to the importance of the independence of those who judge. Journalists and historians must remain independent and cannot become lobbyists. Their personalities hinge on their veracity, their integrity and their independence. They help persistent facts to withstand power. The Edelman Trust Barometer finding that despite considerable confusion, 2017 saw an increase in people's confidence in experts and quality journalism seems promising.

Arendt compared the impartial judgment of historians with that of judges, but also with that of witnesses and professional journalists (Arendt, 2006: 255). The separation 
of powers, which includes the independence of the judiciary, not only guarantees the impartiality of the judiciary but also the area of truth within its framework. That is why autocratic attacks on the constitution and the independence of the judiciary are so alarming. With plurality they undermine the truth in favor of the arbitrariness of the majority. Hence there are targeted attacks on the independence of the judiciary in order to weaken the core elements of the republic: democracy, fundamental rights, and the rule of law. ${ }^{3}$

Arendt adds another aspect: it is not only about journalists, judges and historians, but about all of us, the citizens who shape civil society in the republican sense through their actions and ability to judge. The foundations of the republic, once discussed and adopted by constituent bodies such as parliaments and courts, must be discussed critically time and again. Just as freedom exists only when it is practiced, so can other republican values only be defended if they are discussed and reaffirmed concretely. Why is there a general ban on torture if you think it could save a life under certain circumstances? Why does the right to asylum remain valid when it has been granted to hundreds of thousands at the same time? Why does a republic need an independent judiciary? Why do we allow those with whom we cannot agree to speak with words that are difficult to bear?

Finally, Arendt speaks of the "joys and gratifications of free company" which "are to be preferred to the doubtful pleasures of holding domination" (Arendt, 2006: 242). This joy is the emotional side of independent judgment, and what unites these men and women here is their ability to judge not only other people's opinions but also the quality of other people. Who we want to be with does not depend on political programs or statements, but on the personality of others, on their integrity. The idea goes back to Kant and before him to the early Enlightenment. It clearly contradicts our values and our practice of utilitarianism, our individualism and conformism, our only quantitatively understood plurality. This is the path Arendt offers as a solution to the current crisis.

\section{References}

Arendt H. (1958) The Human Condition, Chicago: University of Chicago Press.

Arendt H. (1972) Lying in Politics: Reflections on the Pentagon Papers. Crises of the Republic, New York: Harcourt, Brace \& Jovanovich, pp. 3-47.

Arendt H. (1979) On Hannah Arendt. Hannah Arendt: The Recovery of the Public World

(ed. M. A. Hill), New York: St. Martin’s Press, pp. 301-339.

Arendt H. (2006) Truth and Politics. Between Past and Future: Eight Exercises in Political Thought, New York: Penguin Books, pp. 223-259.

3. Susanne Baer, judge at the German Federal Constitutional Court, explained: "The talk and acts that need to worry us today are not just critical. Rather, they are attacks on the foundation of constitutionalism, with the intent to do away with courts that deserve the name. This happens when people, or governments, refuse to comply with rulings from the ECHR or reject the very idea of the ICC, which keeps happening. Then such fundamental rejection, which is different from critique, is not the problem of that one court alone. Rather, it is the problem of all who care for constitutionalism" (Council of Europe, 2017). 
Arendt H. (2017) Wie ich einmal ohne dich leben soll, mag ich mir nicht vorstellen: Briefwechsel mit den Freundinnen Charlotte Beradt, Rose Feitelson, Hilde Fränkel, Anne Weil und Helen Wolff (eds. I. Nordmann, U. Ludz), München: Piper.

Bauman Z. (2017) Retrotopia, Berlin: Suhrkamp.

Bettetini M. (2003) Eine kleine Geschichte der Lüge: Von Odysseus bis Pinocchio, Berlin: Wagenbach.

Butter M. (2018) "Nichts ist, wie es scheint": Über Verschwörungstheorien, Berlin: Suhrkamp.

Colliot-Thélène C. (2017) Democracy and Subjective Rights: Democracy without Demos, ECPR Press.

Council of Europe (2017) Venice Commission: Joint Council on Constitutional Justice. Mini Conference Courageous Courts: Security, Xenophobia and Fundamental Rights, Karlsruhe, Germany, 19 May.

Crouch C. (2004) Post-Democracy, Cambridge: Polity.

Dietz S. (2003) Die Kunst des Lügens: Eine sprachliche Fähigkeit und ihr moralischer Wert, Reinbek: Rowohlt.

Edelman (2018) 2018 Edelman Trust Barometer. Available at: https://www.edelman.com/ trust-barometer (accessed 18 November 2018).

Feuerbach L. (2017) Das Muster der Verschwörung. Frankfurter Allgemeine, October 30. Ganzfried D. (2002) . . alias Wilkomirski - Die Holocaust-Travestie: Enthüllung und Dokumentation eines literarischen Skandals, Berlin: Jüdische Verlagsanstalt.

Gutjahr R. (2018) "An Deiner Stelle würd ich mir in Die Hose scheissen, das meiner Tochter auch mal was passieren könnte". Die Zeit, no 4, January 18.

Hersh S. M. (2003) Selective Intelligence: Donald Rumsfeld Has His Own Special Sources. Are They Reliable? The New Yorker, May 12. Available at: https://www.newyorker. com/magazine/2003/05/12/selective-intelligence (accessed 24 October 2018).

Heuer W. (2016) Föderationen: Hannah Arendts politische Grammatik des Gründens, Hannover.

Illouz E. (2007) Gefühle in Zeiten des Kapitalismus, Berlin: Suhrkamp.

Illouz E. (2017) Interview. Frankfurter Allgemeine, January 30.

Kant I. (1898) On a Supposed Right to Tell Lies from Benevolent Motives. Critique of Practical Reason and Other Works on the Theory of Ethics, London: Longmans, Green \& Co, pp. 361-365.

Keane J. (2015) Die neuen Despotien: Vorstellungen vom Ende der Demokratie. Merkur, vol. 69, no 790, pp. 18-31.

Keane J. (2018) Reflections on Post-Truth. Paper delivered at the WZB (17 January 2018). Kreide R. (2016) The Silence of Political Liberalism. Eurozine, May 31. Available at: http:// www.eurozine.com/the-silence-of-political-liberalism/ (accessed 24 Octover 2018).

Machowecz M. (2017) Oh, Ostmann! Die Zeit, 29 September.

Nanz P., Leggewie C. (2016) Die Konsultative: Mehr Demokratie durch Bürgerbeteiligung, Berlin: Wagenbach. 
Nietzsche F. (2006) On Truth and Lies in a Nonmoral Sense. The Nietzsche Reader (eds. K. A. Pearson, D. Large), Malden: Blackwell, pp. 115-123.

Reybrouck D. van (2016) Against Elections: The Case for Democracy, Bodley Head: Random House.

Stangl W. (2018) Mentiologie: Online Lexikon für Psychologie und Pädagogik. Available at: http://lexikon.stangl.eu/6oo8/mentiologie/ (accessed 17 January 2018).

Strauss L. (1959) What is Political Philosophy?, New York: Free Press.

Zielonka J. (2018) Counter-Revolution: Liberal Europe in Retreat, Oxford: Oxford University Press.

\section{Соблазны лжи}

\section{Вольфганг Хойер}

Приват-доцент, Институт политических наук им. Отто Зура, Свободный университет Берлина Главный редактор журнала HannahArendt.net

Адрес: Ihnestraße 21, Berlin, Germany 14195

E-mail: wolfgang.heuer@gmx.de

Ложь сопровождает нас, она паразитирует на истине и является неотъемлемой частью нашей повседневной жизни. Но как мы можем ограничить ложь и предотвратить разрушение правды? Этот вопрос особенно актуален в связи с новым феноменом так называемой «постправды» с его фейковыми новостями, теориями заговора и популистской пропагандой. Здесь может оказаться полезным обращение к арендтовскому анализу отношений между правдой и ложью в политике. Для защиты достоверности необходима истина, но в то же время фактическая истина противостоит безграничной свободе слова и действий, или, говоря словами Арендт, нашему широкому образу мысли. Воображение это общая основа для творчества, мысленного построения другого мира, но также и для лжи. Таким образом, политика и ложь структурно очень близки, хотя, конечно, не одно и то же. Современные популистские движения используют ложь, чтобы подорвать доверие к политикам и средствам массовой информации. Границы между правдой, ложью, отрицанием реальности, выдуманными истинами, а также антисемитизмом и расизмом стираются. В конспирологических теориях потеря чувства реальности достигает своего апофеоза. В отличие от лжи, они предлагают закрытый параллельный мир, в котором ничего не происходит случайно и ничто не является тем, чем кажется. Термин Зигмунта Баумана «ретротопия» указывает на то, что глобализация и технологические изменения приводят к растущему уровню неопределенности и дискредитации политики, что отвечает популистским целям. Республиканизм Арендт предлагает альтернативу популизму и потребительскому либерализму: защиту фактов, просвещенный критицизм и концепцию качественной множественности вовлеченных граждан.

Ключевые слова: правда, пост-правда, ложь, широкий образ мысли, множественность 